\title{
Chromosomal abnormalities in ascitic fluid from patients with alcoholic cirrhosis
}

\author{
A TO, H T BOYO-EKWUEME, M C POSNANSKY, D V COLEMAN
}

\begin{abstract}
Cytology and cytogenetics were used to study ascitic fluid obtained from five patients with alcoholic cirrhosis. Cytological examination showed that all fluids contained numerous mesothelial cells and some leucocytes. Cytogenetic analysis showed abnormal karyotypes in cultured cells from all five patients and in uncultured cells from three. A consistent abnormality was the presence of spreads with over 70 chromosomes. Clones of abnormal cells, with marker chromosomes, pseudodiploidy, or aneuploidy, in an effusion are characteristic of malignancy; the abnormal karyotypes fulfilled these criteria.

This finding of abnormal karyotypes indicates that transformation of the mesothelium can occur in vivo, and such a reaction may be a reflection of the mutagenic effect of alcohol.
\end{abstract}

\section{Introduction}

Chromosomal aberrations have often been shown in the cells of malignant serous effusions, and cytogenetic analysis may be used for diagnosis. ${ }^{1-3}$ The combined use of cytogenetics and cytology increases accuracy, and we have used both methods in investigating effusions from over 100 patients during the past two years. In most cases cytogenetic findings agreed with the final clinical diagnosis. ${ }^{4}$ In five patients both cytological findings and the final clinical diagnosis were benign, when cytogenetic analysis clearly showed abnormal karyotypes; all five patients had alcoholic cirrhosis. These five patients had a long history of alcohol abuse, and the diagnosis of alcoholic cirrhosis was supported by the results of clinical and laboratory tests including hiver biopsy. We report the results obtained in these patients.

\section{Materials and methods}

Cytological smears were prepared from the sediment after centrifugation, stained by Papanicolaou, Giemsa, periodic acid-Schiff and Alcian blue methods, and examined under light microscopy.

Cytogenetic studies were carried out on both uncultured and cultured cells. A minimum of $20 \mathrm{ml}$ fluid was centrifuged and the cell pellet resuspended in $5 \mathrm{ml}$ mixture 199. Colchicine was added at a concentration of $5 \mu \mathrm{g} / \mathrm{ml}$ and the suspension incubated for two hours at $37^{\circ} \mathrm{C}$. The cells were harvested and prepared for chromosome analysis using standard methods.

A short-term culture was set up to increase the number of cells in metaphase available for analysis. The cells were seeded into $25 \mathrm{~cm}^{2}$ Falcon flasks containing $5 \mathrm{ml}$ culture medium (Wellcome mixture 199 (TC 199) plus $20 \%$ fetal calf serum plus $1 \%$ glutamine). They were incubated in an atmosphere of $5 \% \mathrm{CO}_{2}$ and $95 \%$ air at $37^{\circ} \mathrm{C}$, the medium being renewed every three days. The cultures were treated

Cytology and Cytogenetics Unit, Department of Pathology, St Mary's Hospital Medical School, London W2 1PG

A TO, BSC, research assistant

H T BOYO-EKWUEME, MB, DCP, honorary registrar (present address: department of pathology, University Hospital, Lagos, Nigeria)

M C POSNANSKY, medical student (present address: faculty of medicine, University of Edinburgh)

D V COLEMAN, MD, MRCPATH, consultant with $2 \%$ trypsin just before confluence, generally within six to 10 days, and processed for chromosome analysis.

Chromosomes from peripheral blood specimens were prepared by a modification of the technique of Moorhead et al. ${ }^{5}$ Both banded and unbanded preparations were examined.

\section{Results}

Cytological examination showed that all fluids contained numerous mesothelial cells and some leucocytes. Cells from one patient showed such pronounced anisonucleosis that they were thought to be malignant and were reported as such. In view of the clinical diagnosis of cirrhosis the smear was reviewed and the abnormal cells were thought to be proliferating mesothelial cells.

Abnormal karyotypes were found in cultured cells from all five patients and in uncultured cells from three (table). A consistent abnormality was the presence of spreads with more than 70 chromo-

Cytological and cytogenetic findings in five patients with alcoholic cirrhosis

\begin{tabular}{|c|c|c|c|c|c|c|}
\hline \multirow{2}{*}{$\begin{array}{l}\text { Case } \\
\text { No }\end{array}$} & \multirow{2}{*}{$\begin{array}{c}\text { Age } \\
\text { (years) }\end{array}$} & \multirow[t]{2}{*}{ Sex } & \multirow{2}{*}{$\begin{array}{c}\text { Diagnosis } \\
\text { confirmed } \\
\text { by liver } \\
\text { biopsy }\end{array}$} & \multicolumn{2}{|c|}{$\begin{array}{l}\text { Cytogenetic analysis with } \\
\text { ascitic fluid: }\end{array}$} & \multirow{2}{*}{$\begin{array}{l}\text { Peripheral } \\
\text { blood }\end{array}$} \\
\hline & & & & Uncultured & Cultured & \\
\hline 1 & 75 & $\mathbf{M}$ & Yes & No metaphases & Abnormal & Not done \\
\hline 2 & 60 & F & Yes & No metaphases & Abnormal & Normal \\
\hline $\begin{array}{l}3 \\
4 \\
5\end{array}$ & $\begin{array}{l}62 \\
64 \\
55\end{array}$ & $\begin{array}{l}\mathbf{F} \\
\underset{M}{\mathbf{M}}\end{array}$ & $\begin{array}{c}\text { Not done } \\
\text { Yes } \\
\text { Yes }\end{array}$ & $\begin{array}{l}\text { Abnormal } \\
\text { Abnormal } \\
\text { Abnormal }\end{array}$ & $\begin{array}{l}\text { Abnormal } \\
\text { Abnormal } \\
\text { Abnormal }\end{array}$ & $\begin{array}{c}\text { Normal } \\
\text { Abnormal } \\
\text { Abnormal }\end{array}$ \\
\hline
\end{tabular}

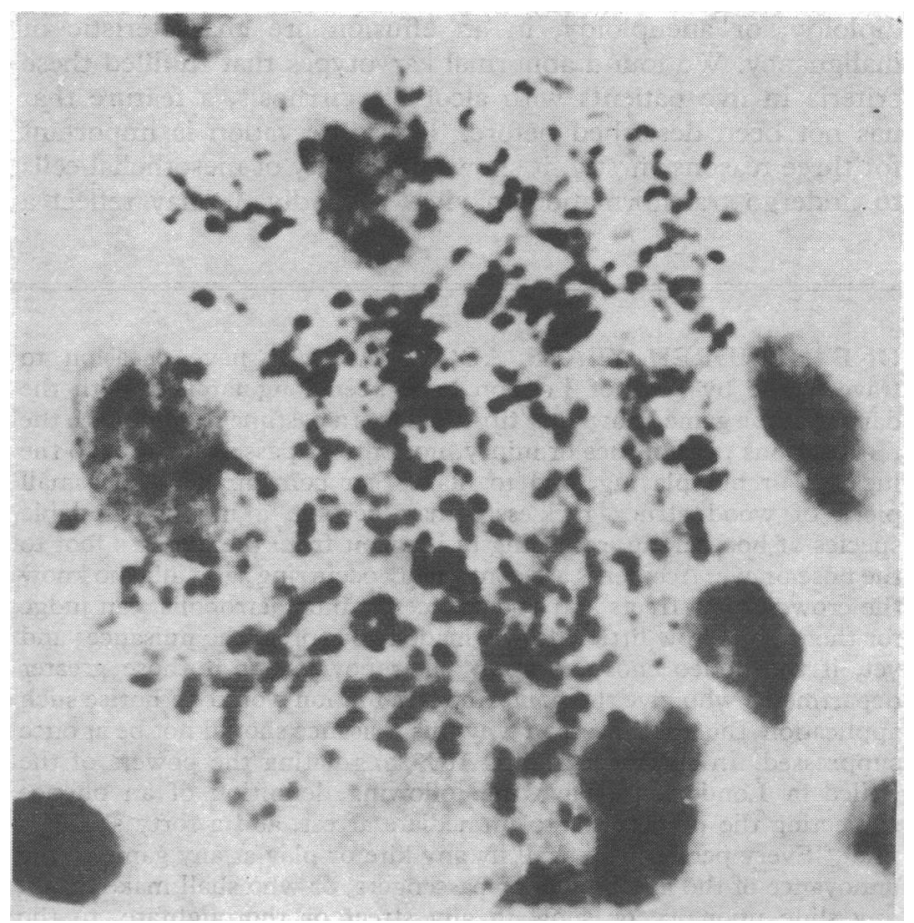

FIG 1-Abnormal karyotype showing aneuploidy and minute marker chromosomes (Giemsa). 
somes. In three patients numerous, minute marker chromosomes (fig 1) were present, and in two large acrocentric marker chromosomes were observed in hyperdiploid and pseudodiploid cells (fig 2).

Abnormal karyotypes were detected in peripheral blood cultures in two patients: a dicentric marker chromosome and endoreduplication in one and seven hyperdiploid spreads containing from 49 to over 100 chromosomes in another.

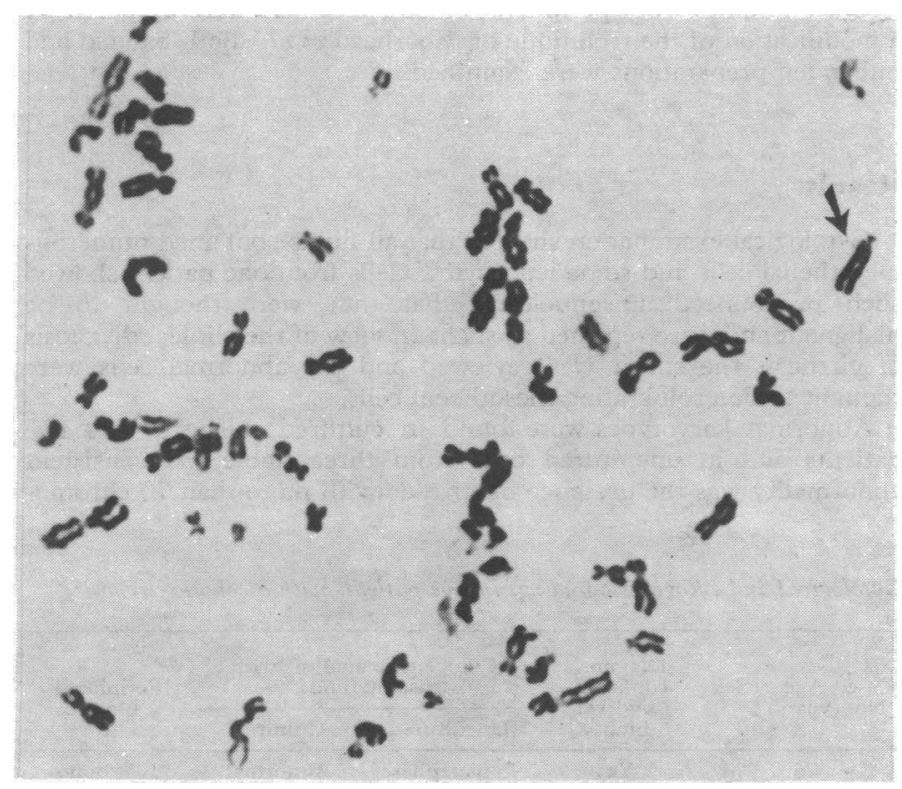

FIG 2-Abnormal karyotype showing (arrowed) marker chromosome (Giemsa).

\section{Discussion}

Clones of abnormal cells, with marker chromosomes, pseudodiploidy, or aneuploidy, in an effusion are characteristic of malignancy. We found abnormal karyotypes that fulfilled these criteria in five patients with alcoholic cirrhosis, a feature that has not been described before. This observation is important for three reasons: firstly, it shows the ability of mesothelial cells to undergo transformation in vivo; secondly, it may reflect a mutagenic effect of alcohol; and, thirdly, it means that falsepositive results may be obtained.

The cytological diagnosis of malignancy in serous effusions depends on the recognition of morphological differences between malignant and non-malignant cells. When malignant cells are $\widehat{\overparen{C}}$ small and characterised by isonucleosis they are often difficult to distinguish from actively proliferating mesothelial cells. This is particularly likely in fluid from patients with alcoholic $\mathbb{D}$ cirrhosis but occasionally may also be found in other benign $m$ diseases. Alcohol may be mutagenic in plants, ${ }^{6}$ experimental animals, ${ }^{7}$ and man. ${ }^{6}$ Chromosomal aberrations have been found in the peripheral blood of chronic alcohol users. ${ }^{8}{ }^{9}$ The effect seems to be mediated via acetaldehyde, which induces chromatid-을 type aberrations in normal lymphocyte cultures. ${ }^{6}$ Mutagenic $\frac{O}{\bar{T}}$ activity has recently been found in the urine of patients with alcoholic cirrhosis who were non-smokers. ${ }^{10}$

This is the first time that transformation of the mesothelium, characterised by the development of abnormal karyotypes, has $\rightarrow$ been described. The abnormalities are reminiscent of those that occur in dysplastic lesions of the cervix, lung, and other epithelial $\vec{\omega}$ surfaces. Four of the present patients were well; there was nothing to suggest that the chromosomal abnormalities indicate $\frac{\partial}{3}$ the onset of malignancy.

We should like to than

medical o unit, St Mary's Hospital, for permission to report these cases.

\section{References}

${ }^{1}$ Benedict WF, Porter IH. The cytogenetic diagnosis of malignancy in $N$ effusions. Acta Cytol 1972;16:304-6.

2 Dewald G, Dines DE, Weiland LH, Gordon H. Usefulness of chromosome examination in the diagnosis of malignant pleural effusions. $N$ Engl $\mathcal{f}^{-}$ Med 1976;295:1494-1500.

${ }^{3}$ Korsgaard $R$. Chromosome analysis of malignant human effusions in vivo. Scand $\mathcal{F}$ Respir Dis 1979; suppl 105:7-100.

4 Watts KC, Boyo-Ekwueme HT, To A, Posnansky MC, Coleman DV. Chromosome studies on cells cultured from serous effusions; use in routine cytological practice. Acta Cytol (in press).

5 Moorhead PS, Nowell PC, Mellman WJ, Battips DM, Hungerford DA. Chromosome preparations of leucocytes cultured from peripheral blood. ڤِ Exp Cell Res 1960;20:613-6.

6 Obe G, Ristow H. Mutagenic, cancerogenic and teratogenic effects of alcohol. Mutat Res 1979;65:229-59.

7 Badr FM, Badr RS. Induction of dominant lethal mutation in male mice 3 by ethyl alcohol. Nature 1975 ;253:134-6.

${ }^{8}$ Mitelman F, Wedstein J. Chromosome aberrations in chronic alcoholics. Lancet 1978;i:216.

- Obe G, Herha J. Chromosomal damage in chronic alcohol users. Humangenetik 1975;29:191-200.

10 Gelbart SM, Sontag SJ. Mutagenic urine in cirrhosis. Lancet $1980 ; \mathrm{i}: 894-6$.

(Accepted 7 April 1981)
ONE HUNDRED YEARS AGO All who have occasion to traverse the by-ways of London have been long familiar with the danger of the game known as "tip-cat." It is a pastime fraught with the most serious possibilities of injury, not only to passers-by, but to the luckless urchin playing, and to his or her companions. The small piece of wood struck recklessly may become a most formidable species of boomerang, returning in its orbit from the player's foot to the nose or eye. Accidents are continually occurring; and all who know the crowded by-streets and open spaces of our metropolis, can judge for themselves how little effort is made to suppress the nuisance; and yet, if the police chose to apply their powers, or if those greater departments who give the police life and motion would authorise such application, there is no reason why this nuisance should not be at once suppressed. In an Act as old as 1839, regulating the powers of the police in London, we have the following definition of an offence subjecting the perpetrator to immediate arrest, and a forty shillings fine: "Every person who shall fly any kite or play at any game to the annoyance of the inhabitants or passengers, or who shall make or use any slide upon ice or snow in any street or thoroughfare, to the common danger of the passengers." This subsection of the Metropolis Police Act is, however, though still in full force in the Statute-book, practically regarded as an obsolete provision, like the old injunction to $\widetilde{\sim}$ magistrates to bring up people guilty of witchcraft. The string of a $D$ kite coming across one's nose, or jerking off a hat, might be a serious inconvenience, especially if the kite-flyers became very numerous; but any annoyance in this respect against which the Legislature of $1839 \mathrm{~N}$ could have dreamed of providing, is utterly trivial in comparison with $\omega$ the danger of losing one's eye when an involuntary participant in the game of "tip-cat." We can understand that a very natural disposition 6 to look with indulgence on the efforts after amusement of the childhood $\bar{\varnothing}$ in our great towns is at the bottom of the indifference of which we $\stackrel{?}{?}$ complain. The more reasonable provision is made for the entertain- 0 ment of children the better. The first consideration is, that the streets 0 of a great community like that of London shall be traversable without $\vec{\Phi}$ danger to the multitudes whom business and duty call to penetrate $\frac{?}{\mathbb{D}}$ sometimes to its most remote corners. With the words of the Metro- $\varrho$ polis Police Act before us, and evidence of the serious mischief resulting from the prevalence of this stupid pastime, no theory or $\delta$ philanthropy can acquit those who are responsible for good order in our streets of the most supine negligence. (British Medical fournal, 1881.) 